The greater availability of technical scholarships and fellowships might well serve as a means of attracting suitable personnel to industrial employment. The extension of fellowship facilities arailable for those who seck experience abroad is extremely valuable, particularly if these are awarded to men who have already had sufficient experience to know definitely in what particular directions they wish to supplement their existing knowledge. In the past, many educational opportunities of this type have not been used to the best advantage due to the immaturity of those receiving the awards, who have not had sufficient experience to appreciate fully that educational and industrial methods can never be transferred wholly from one country to another because social and economic conditions differ. Some industrial organizations have established research fellowships, whereby university staffs can spend time in industrial research organizations, which provides experience of inestimable value to the fellowship holder on his return to academic life.

As yet there is no clearly defined and assured path by which a youth can proceed through the various stages of education into industrial employ. ment. The national system of education provides the means whereby those of suitable ability can obtain education and training up to and including the university or technical college level, but the practical training in industry and an assured start in a job is at present fortuitous. In this direction there is room for greater co-operation by industry to ensure the completion of the industrial training and a start in the chosen career. Such an arrangement would give direction and impetus to the various stages of preparation between school or college and industry, would cut down some of the time spent in obtaining what may be unnecessarily detailed technical knowledge, and moreover would reliere both the youth and his parents of a good deal of anxiety.

Greater co-operation than at present exists between education and industry is essential in regard to the syllabuses of workshop and technical studies appropriate to the educational level at which entrance into industry is made. Equally also, co-operation in needed to ensure the adequacy and up-to-date-ness of the laboratory and workshop equipment of the technical institutions and universities.

In this address I have purposely stressed the technical aspects of education for industry, since these to a considerable degree serve also as a basis for the industrial education of the personnel in those branches of industry not directly of a technical character. In so doing I am acutely conscious of the risk that, speaking as an industrialist, I may convey the impression that industry is concerned with the education of its personnel in a narrow sense only. This is far from being the case. All education should be on the most liberal lines, and even to meet the urgent needs of industry no technical specialization should be permitted which excludes the possibility of time being devoted to broadening the mind and equipping the individual to play his part most worthily in the community in which he is placed.

\title{
GAS PRODUCERS FOR MOTOR-CARS
}

$\mathrm{T}$ HE appearance on a road in the London district of an omnibus with a trailer carrying a gas-producing apparatus to provide gas as fuel for its engine is a spectacular event which marks an important stage in mechanical propulsion in Great Britain. Although the method is by no means new, its adoption, even if only on an experimental scale, by a responsible authority on one of its public services, raises it from the category of the practically neglected to a position as one of the recognized possible alternatives to the use of liquid fuel. The trailer is not an essential part of the apparatus, and as soon as practical details have been settled by experience it will be possible to embody the gas producer in the vehicle so as to constitute a self-contained unit; but in the case of the existing pattern of omnibuses there is no surplus space in which such an apparatus can be placed. In the case of the private car or delivery. van, there is usually room for the required size of gas generator and little difficulty need be experienced in mounting it and its accessories quite conveniently.

In the issue of Nature of Nay 6, p. 771, some notes were published on a paper read before the Institute of Fuel by Goldman and Clarke Jones entitled "The Nodern Portable Gas Producer" (J. Inst. Fuel, 12, 63, Feb. 1939). The authors argued in favour of official recog. nition of portable gas producers as a means of supplying power for motor-vehicles. Now, nearly. twelve months later, the argument for recognition is greatly strengthened, for economists have assured us that transport is the life-blood of modern conditions. Yet now transport is greatly restricted and, for lack of petrol, many cars have 
been laid up indefinitely or their use limited. The possibilities claimed for this new method of power production, therefore, deserve fuller examination, and, as the fuel is home-produced, those who require a greater degree of use of their cars can consider its adoption. In our carlicr article, the process of gasification was described and readers may now wish to have information regarding the British-made apparatus referred to in the paper.

This plant has been successfully mounted on private cars of medium power, on transport and other vehicles, and is so designed as to require no special skill on the part of the driver. A supply of fuel is dropped into a hopper placed above the generator, where a moderate fire is maintained and a gas of high calorific value produced. The gas is cooled by the air going to the generator, to which some stcam is also supplied in order to keep the temperature below the ash fusion point, thus climinating a possible source of trouble. On its way to the engine the gas is passed through a cleaner to remove dust. Photographs reproduced in the paper show the complete apparatus as fitted to a Humber car, a Bedford lorry, and to a tractor hauling a plough, and in each case the addition has been effected without inconvenience or unsightliness. The first lighting of the fire-a matter of no great difficulty - takes ten or twelve minutes, and it does not require to be relit afresh each day. The hopper is charged occasionally with fuel, and this can be done without stopping the engine.

Suitable fucls, such as anthracite or one of the low-temperature cokes-for example, coalitealthough abundant, are certainly not so conveniently obtainable as was petrol in ordinary times. This difficulty would be overcome, but in any event users could easily store ample supplies if the authorities granted permission. As regards operating costs, the claim is made that the advantage lies with the gas producer. On the basis of the prices of a year ago, the total operating costs for a $1 \frac{1}{2}$-ton vehicle making a weekly round of 600 miles would be $£ 11$ 10s. per week when petrol is used and $£ 9$ 17s. in the case of the gas producer. It may therefore be seen that the system is practicable and not necessarily expensive.

Official approval of a form of gas producer was conveyed by an announcement made by the Secretary of Mines in the Houso of Commons last week. He said that the Government, recognizing that in time of war it is clearly in the national interest to make the best possible use of homeproduced substitutes for imported oil, had some time ago set up a committee to consider the problems of such gas producers. As a result, not only has the use of producer gas been sanctioned, but concessions have also been made to ensure that users do not suffer disadvantage in making the change-over.

\section{O B I T U A R I E S}

\section{Prof. A. A. J. de 'Sigmond}

$I^{\mathrm{T}}$ $T^{\prime}$ is with great regret that wo record the death of Prof. Alexius A. J. de 'Sigmond, professor of agricultural chemistry and technology and soil scienco in the Royal Hungarian Palatino-Joseph University of Technical and Economic Sciences of Budapest, and formerly director of the Royal Hungarian Institute of Chemistry and Central Experimental Station at Budapest. Coming of an old aristocratic Transylvanian family, ho found himself at the end of tho War of 1914-18 compelled to choose between his work which lay in Hungary or his estates which woro in the country ceded to Rumania. Ho decided for his work.

To English men of science de 'Sigmond was best known through his investigations on the alkali soils in Hungary, which ho described in publications of the Imporial Bureau of Soil Science and the University of California Press. Although thero were certain spocial features about these soils, ho had carried out his rescarches on broad lines, which mado the results particularly interesting and helpful to thoso engaged on soil improvemont, reclamation, and similar problems in many other parts of the world, especially the semi-arid regions. His other important branch of study was soil classification, which he dealt with at length in his book on soil science; this was written in Hungarian, but in somowhat abbroviated form it was translated into English by Dr. Yolland under the title "The Principles of Soil Scienco". His classification had the doublo merit of being comprohonsive and based on the chemical composition of the soil : it was not intended to bo final, but it satisfactorily filled a number of gaps in other systems. It has not been universally adopted, nor indeed has any as yet; but it ropresents a distinct addition to knowledge on a very difficult and important subject.

Prof. 'Sigmond was a regular attendant at meetings of the International Society of Soil Science, of which he was an honorary member, and he was always a welcomo guest in any international group by reason of his wide linguistic abilities and broad sympathies. He was a man of great personal charm and artistic taste; he was very fond of music; and altogother a good type of the cultured aristocracy of central Europo now unhappily fast disappearing, to the great loss of our civilization.

E. J. RusselL. 